\title{
Investigatıon Of Spiritual Well-Being Palliative Care Of Patients
}

\author{
Fadime Çınar $^{1}$, Turgay Şirin ${ }^{2}$ \\ ${ }^{1}$ Sabahattin Zaim University, Faculty of Health Sciences, Health Management, Istanbul, Turkey \\ ${ }^{2}$ Sabahattin Zaim University, Faculty of Human And Social Sciences, Psychology, Istanbul, Turkey
}

DOI: https://doi.org/10.15520/ijmhs.v9i7.2643

Accepted 15 Jul 2019; Received 15 Jun 2019; Publish Online 29 Jul 2019

Reviewed By: Dr.

Daniel V.

Department: Medical

* Corresponding author.

†Email: fadime.cinar@izu.edu.tr.

\begin{abstract}
Background: One of the indispensable aspects of the philosophy of holistic care, and negative situations such as life-threatening illness, spiritual well-being, which is defined as the search for a relationship with a divine soul, is a requirement that must be met in order to maintain the existence of the individual. The patient's need for social and spiritual well-being increases even more in cases of long-term treatment, such as cancer, that reduce the quality of life. Determining and meeting the spiritual needs of the individual in the difficult times of the crisis can be realized by determining the spiritual well-being levels of the individuals and by providing the individual spiritual care. This study was conducted to determine the level of the spiritual well-being of palliative care patients diagnosed with cancer. Methods: This is a descriptive study. The population of the study consisted of 124 patients diagnosed with cancer who were hospitalized in the palliative unit between January and August 2018 and were treated in two state hospitals operating on the European side of Istanbul. The sample consisted of 111 people with voluntary participation and communication. Personal Information Form and Spiritual Well-being Scale were used to collect data. Data were evaluated by one-way analysis of variance (oneway anova) and significance (t-test) of the difference between the two means. Results: The total score averages from the spiritual good scale of individuals participating in the Study were determined to be good with $\mathrm{x}=4,15$. In terms of the level of education of Scale scores, only "Anomi" is significantly differentiated between groups of age, with a total score of the scale, In the sub-dimension of transcendity and the subdimension of "Harmony with Nature" according to the variable metastasis $(p>0.05)$. Conclusion: Spiritual Well-being has a positive effect on the healing process of individuals with impaired health. It helps individuals who have a crisis in life threatening diseases such as Cancer to cope with this crisis and to provide spiritual well-being in the sense of life. In This process, spiritual care initiatives by healthcare professionals can be transformed into a part of the healing process and the spiritual goodness of the individual can be increased. Further research in This area is projected to contribute to the richening of the relevant literature in

Turkey. Key words: Spiritual, spiritual well-being, palliative care, palliative care unit
\end{abstract}

\section{INTRODUCTION:}

Nowadays, a general increase has been observed in chronic diseases that lead to death, such as cancer, ischemic heart and other heart diseases, stroke and hypertensive diseases, respiratory system diseases throughout the world and in our country (American Cancer Society Cancer Statistics Center, 2017, Public Health 
Institution Of Turkey, 2017). This also leads to an increase in the number of people who need palliative care.

Spirituality, which is defined as the search for a relationship with a divine soul, is one of the indispensable dimensions of the philosophy of holistic care. Every human being has a spiritual dimension. Although the word spiritual is used separately from the word religion in the literature, psychologists have defined the terms "religiosity" and "spirituality" in different ways for more than a century (Paloutzian and Park, 2013). However, it can be said that there is a consensus that both concepts are multidimensional. With respect to the general tendency of specialists on these definitions, it can be said that they address religion as a broadband concept and do not separate it from spirituality (Paloutzian and Park, 2013). In brief, it would be correct to say that religious and spiritual phenomena have generally been gathered under the broad-band and wide range of the religious structure or that the terms religion and spirituality have been used interchangeably (Paloutzian and Park, 2013). Therefore, in adverse situations such as lifethreatening diseases, the spiritual needs to be met arise (Çınar and Eti Aslan, 2017). One of the areas where these requirements are intense is palliative care units. Palliative care units are special units in which treatment and care interventions are applied to individuals who are in the final stage of cancer diagnosed with cancer, which cannot meet the self-care requirements where holistic care is a priority. The need for support of social and spiritual well-being of the patient increases as the treatment of cancer is prolonged and the quality of life decreases.

Cancer affects the life style and quality of the individual and his / her family diagnosed due to the disease course and treatment method. From the diagnosis stage of the cancer to the terminal period, it is a disease that creates serious stress for the patients and the treatment team as well as for the patients and the patients. It is a symbol of an unknown danger, anguish and pain, guilt and shame, isolation, chaos and anxiety. Therefore, cancer is not only a medicalphysical disease but also a psychological and psychosocial problem. The diagnosis of cancer is a traumatic experience for the individual and family. According to other diseases, cancer can affect the individual's daily life balance more and the individual and his / her family can affect every physical, psychological, social and economic area. Cancer can have meanings such as influence of adaptation mechanisms for the individual, disruption of future plans and loss of power. Cancer causes anxiety in the patient and her family because her clinical course is uncertain and her treatment cannot be fully guaranteed. The reasons for this concern are the uncertainty issues in cancer, the fear of recurrence of cancer, loss of control, and the existence concerns of life and death (KuzeyliYildirim 2006, Yildiz, et al. 2016).

The word Spirituality is associated with concepts such as religion, belief, spirituality and has been used in many different meanings so far (Yilmaz and Okyay 2009).Spirituality, meaning "Breathing", "Being Alive" is derived from the Latin word "spiritus". To feel life with a wider definition. Spirituality also includes elements that constitute the purpose of his life, except for the individual to Seek relationship with a divine Soul (Narayanasamy 2006, Khairunnisa 2014, Turan and Karamanoğlu 2013).Spiritualism is also defined as "unifying power" affecting body and soul, and also influenced by body and soul (Kostak et al. 2010).

The World Health Organization (WHO), the World Health Organization (WHO), defines health as a state of well-being in terms of physical, social and mental well-being, not only the absence of disease and disability; he 
emphasized that spiritual well-being should also be evaluated. This definition indicates that all dimensions of human beings may be healthy if they are in equilibrium (Atabek and Karadağ, 2013).

Like all other dimensions, the spiritual dimension is a dimension from birth and is part of the identity. All people have a spiritual dimension, whether or not they perform formal religious practices. However, the degree of awareness may change in each individual (Baldacchino, 2006, Toker and Çınar, 2018). The spiritual aspect of man is as important and related to his / her physical, emotional, and social aspects. In the individual care approach, it is emphasized that the physical, spiritual and mental dimension of the human is unique to each other and that these dimensions are related to each other. The spiritual dimension comes to the fore especially in crisis situations where the individual experiences illness, stress, fear of death, questioning the meaning of life and exhausting hope. In particular, life-threatening diseases lead to the emergence of spiritual needs (Toker and Çınar, 2018). Satisfying the individual needs, helping the individual to accept the disease and making plans for the future, increases the hope of life by positively affecting the healing process (Lundbergand and Kerdonfag, 2010, McDowell and South, 2017).

Spiritual well-being, expressed as a spiritual well-being is a form of well-being. It is a concept that contains both spirituality and goodness. Spiritual well-being contains both spirituality and well-being. It has been used to express human good in religious and existential terms. Spiritual well-being is a concept that includes subjects related to life and religion, examining the relationship between himself and the environment and God. There are two dimensions of spiritual well-being. The first is the existential dimension that includes the connection of the individual with the self and the external world. The other is the religious dimension that expresses the relationship of man with divine power. What is essential here is the satisfaction and satisfaction that people get from the relationship with divine power and life ((Ellor and McGregor, 2011, Gow et al. 2011; Fisher, 2007, Unterrainer et al. 2012).

The World Health Organization defines palliative care as "an approach that is aimed at improving the quality of life of patients and their relatives who face a life-threatening disease and that aims for the early diagnosis and treatment of physical, psychosocial and spiritual problems, especially pain" (WHO, 2017). The International Palliative Care Association (IAHPC) describes palliative care as "the care of patients with an active, continuous and advanced disease, the focus of which is to decrease pain and to improve the quality of life" (Doyle and Woodruff, 2013). Palliative care an is an approach that improves the quality of life of the patient and his family by preventing the pain and other physical, psychosocial and spiritual problems in their early stages, by carefully evaluating and treating them when they face problems that threaten the life of the patient and his family. The units where this approach is presented are palliative care units (Elçigil, 2006). In palliative care units, the patients who are in the last stage of their life are not present together with their families and close friends, and they cannot perform their routine habits, cause feelings of loneliness, meaning meaning and value in life and negatively affect their beliefs. This situation, which causes a decrease in the quality of life, increases the need for spiritual support by causing spiritual distress in these individuals (Catania et al.2016).Therefore, the physical and psychological needs of the patients and their spiritual needs must be met in palliative care units. In these units, controlling the pain and other symptoms of the patients, meeting their 
psychosocial and spiritual needs and increasing their quality of life are the main targets (Glare 2005, Elçigil, 2006, Meier 2008, Kalkim, Midilli and Baysal, 2016).

Recent guidelines on the quality of palliative care show that spirituality is an important dimension that should be taken into account when helping patients nearing the end of life. In addition, in the definition of palliative care, the World Health Organization (WHO) highlights the various needs of the patient, including the spiritual dimension (Catania et al.2016). Providing the spiritual well-being of the palliative patients diagnosed with cancer and meeting their spiritual needs is the basis of the holistic health care. Spiritual well-being enhances the ability of these individuals to cope with the disease and the problems they cause and to re-interpret life. However, many of the health workers working in these units disregard the spiritual dimension of the patient and are insufficient to integrate them into the basic care areas. The aim of this study is to determine the level of spiritual well-being of the palliative patients and to determine the practices of spiritual care that will help to use the methods of coping with the life threatening disease condition while maintaining the treatment of cancer. Thus, conflicts between spiritual beliefs and values and health care initiatives can be reduced. In addition, it is thought that the establishment of a healing model based on spirituality between the health care workers and the patient will contribute to the spiritual care.

\section{Method}

\subsection{Purpose of the Research}

The purpose of this descriptive study was to examine the level of spiritual well-being of patients diagnosed with cancer.

\subsection{Place and Time of Research, Universe, Sample}

This study, which is a descriptive and type research, was conducted between January and August 2018. The population of the study consisted of 124 patients diagnosed with cancer who were hospitalized in the palliative unit between January and August 2018 and were treated in two state hospitals operating in the European side of Istanbul. The sample consisted of 110 people with voluntary participation and communication reasons.

\subsection{Data Collection}

The "Personal Information Form" and "Spiritual Well-Being Scale" were used by researchers in the collection of Data to be scanned by the literature.

\section{Personal Information Form:}

Individual Information Form includes questions about age, gender, marital status, cancer localization, time of diagnosis, presence of spreading disease and final treatment method.

\section{Spiritual Well-Being Scale:}

Spiritual Well-being Scale ler which was developed by Ekşi and Kardaş (2017) in accordance with Turkish culture, is an adultoriented scale designed to determine the life and understanding of life by means of personal, social, environmental and transcendental aspects in accordance with human's value and ultimate meaning. As a result of confirmatory factor analysis, 29 items; a structure with three factors called transcendence, harmony with nature and anomy has emerged. The subdimension of "Transcinity" (15 items) "Harmony with Nature" (7 items) is a scale of "Anomi" (7 substances) with a five-fied Likert type. Scoring of items on the Scale ( $1=$ not suitable for me, 2 = not suitable for me, $3=$ Me a little fit, $4=$ It is very convenient to me, $5=\mathrm{Me}$ is fully structured).The highest rated score is 145 , and the lowest is 29 . The higher the Total score, the better the spiritual level of good. When the 
average of These points is taken from 1 to 5 points, the score of 4 and above indicates that the spiritual good is strong.In the analysis of the internal consistency, the scale was determined as the total,886 of Cronbach's Alpha $(\alpha)$ coefficient, for the size of the Transcode, 953 for the Size of the Natural Harmony,,864, Anomi (non-normity), 853. The Scale's alignment indices are ( $\mathrm{x} 2 / \mathrm{SD}=4.11$, RMESEA $=.06, \mathrm{SRMR}=.50, \mathrm{NTHE}=.90, \mathrm{CFI}=.92)$. In This study, the Cronbach Alpha $(\alpha)$ coefficient for the overall and sub-dimensions of the scale calculated within the scope of internal consistency; The overall reliability of the Spiritual Well-being Scale was found to be 725.

\subsection{Method of Data Collection and Ethical Aspects of the Research}

Prior to the Study, the Ethics Committee (Ethics Committee Approval No: 2018/05) was granted permission from Sabahattin Zaim University and the upper management of the hospitals where the research was performed. Verbal and written consent was obtained from the participants in the Research scope. The Researchers were informed about the filling and research of data collection forms.

Participants who agreed to participate in the Survey were given a 1-hour time with the distribute collect method in the researcher's control. This time is finally assembled.

\subsection{Limitations of the Research}

The study was limited to the data of 111 palliative care patients working in two state hospitals operating in the European side of Istanbul in 2018 and the data obtained from the items of the scale.

\subsection{Evaluation of Data}

The data obtained from the questionnaires were entered into the SPSS 25.0 package program and statistical analyzes were performed. The data were analyzed by KolmogorovSmirnov test before the difference analysis. As a result, the Spiritual Well-being Scale was found to be normal distributed in the range of -1.5 to +1.5 (Skewness: -.371, Kurtosis: -.858) (Tabachnick, 2013). For data showing normal distribution, ANOVA and independent group t test were used. The distribution of the questions in the Information Form was interpreted as frequency, percentage, and scale scores as mean, standard deviation. Results were evaluated at $95 \%$ confidence interval, $\mathrm{p}<0.05$ significance level.

\section{Results:}

The mean age of the participants was $46 \pm 1.45$ and $63.64 \%$ of the sample was Women $(n=70)$ and $36.36 \%(n=40)$ were Men. No more than $37.27 \%$ of the participants (41 people) were in the $41-50$ age range; $35.45 \%(n=39)$ of high school level; graduates. In terms of marital status, $78.18 \%$ of the sample was married $(\mathrm{n}=$ $86) ; 21,82 \%(\mathrm{n}=24)$ is single. When the sample was examined in terms of occupation, a maximum of $31.82 \%(n=35)$ of the sample was housewife, and $25.45 \%(\mathrm{n}=28)$ of the patients were in the gastrointestinal tract; $\%$ and $33.64 \%$ $(\mathrm{n}=37)$ had other cancer localization. When the time of diagnosis of the sample participating in the study is examined, the most frequent; 49,09\% ( $\mathrm{n}=54$ ) 4-7 months of time passed, in terms of the presence of spreading disease as a result of the study of the rate of those who say that the spread of $16.36 \%(n=18)$, while the rate of those who say $83.64 \%(n=92)$. When the last treatment method was investigated, it was found that $44,55 \%(\mathrm{n}=49)$ received radiotherapy treatment (Table 1$)$. 
Table 1: Participant characteristics $(n=111)$

\begin{tabular}{|c|c|c|c|}
\hline Age & Frequency $(\mathrm{n})$ & Percentage (\%) & Cumulative $\%$ \\
\hline $17-30$ age & 17 & 15,45 & 15,45 \\
\hline $31-40$ age & 12 & 10,91 & 26,36 \\
\hline $41-50$ age & 41 & 37,27 & 63,64 \\
\hline $51-60$ age & 19 & 17,27 & 80,91 \\
\hline $61+$ & 21 & 19,09 & 100 \\
\hline Total & 110 & 100 & \\
\hline \multicolumn{4}{|l|}{ Gender } \\
\hline Female & 70 & 63,64 & 63,64 \\
\hline Male & 40 & 36,36 & 100 \\
\hline Total & 110 & 100 & \\
\hline \multicolumn{4}{|l|}{ Education } \\
\hline Primary school & 29 & 26,36 & 26,36 \\
\hline Middle School & 22 & 20 & 46,36 \\
\hline High school & 39 & 35,45 & 81,82 \\
\hline License & 12 & 10,91 & 92,73 \\
\hline Master's Degree & 8 & 7,27 & 100 \\
\hline Total & 110 & 100 & \\
\hline \multicolumn{4}{|l|}{ Marital status } \\
\hline The married & 86 & 78,18 & 78,18 \\
\hline Single & 24 & 21,82 & 100 \\
\hline Total & 110 & 100 & \\
\hline \multicolumn{4}{|l|}{ Profession } \\
\hline Housewife & 35 & 31,82 & 31,82 \\
\hline Messenger & 1 & 0,91 & 32,73 \\
\hline Officer & 14 & 12,73 & 45,45 \\
\hline Workers-Employees & 30 & 27,27 & 72,73 \\
\hline Student & 11 & 10 & 82,73 \\
\hline Retired & 19 & 17,27 & 100 \\
\hline Total & 110 & 100 & \\
\hline \multicolumn{4}{|l|}{ Cancer Localization } \\
\hline Head \& Neck & 7 & 6,36 & 6,36 \\
\hline Gastrointestinal & 28 & 25,45 & 31,82 \\
\hline Lungs & 15 & 13,64 & 45,45 \\
\hline Hepatobilli is / Pancreas & 23 & 20,91 & 66,36 \\
\hline Other & 37 & 33,64 & 100 \\
\hline Total & 110 & 100 & \\
\hline \multicolumn{4}{|l|}{ Diagnosis Time } \\
\hline 0-3 Months & 38 & 34,55 & 34,55 \\
\hline 4-7 Months & 54 & 49,09 & 83,64 \\
\hline 8-12 Months & 15 & 13,64 & 97,27 \\
\hline 13 Months and Above & 2 & 1,82 & 99,09 \\
\hline 21 & 1 & 0,91 & 100 \\
\hline Total & 110 & 100 & \\
\hline \multicolumn{4}{|l|}{ Spread Disease } \\
\hline There is & 18 & 16,36 & 16,36 \\
\hline No & 92 & 83,64 & 100 \\
\hline Total & 110 & 100 & \\
\hline \multicolumn{4}{|l|}{ Latest Treatment } \\
\hline Chemotherapy & 46 & 41,82 & 41,82 \\
\hline Radiotherapy & 49 & 44,55 & 86,36 \\
\hline Chemotherapy + Radiotherapy & 15 & 13,64 & 100 \\
\hline Total & 110 & 100 & \\
\hline
\end{tabular}


First of all, the scale scores of the sample were evaluated. The mean of the am transcendence boyut subscale was $4.52 \pm 0.45$; ,6 Adaptation to Nature 7 sub-dimension average $(4.37 \pm$
0.62); The average size of the) Anomi as1 subdimension $(3.00 \pm 1.07)$; The mean of Tablo Spiritual Well-being Scale was found as $4,15 \pm$ 0,46 (Table 2).

Table 2: Mean scores of Spiritual Well-being Scale and Sub-dimensions

\begin{tabular}{|l|c|c|c|c|c|c|c|}
\hline & $\mathrm{N}$ & Mean & Std. Deviation & \multicolumn{2}{|c|}{ Skewness } & \multicolumn{2}{|c|}{ Kurtosis } \\
\hline Transcendence & 110 & 4,52 & 0,45 & $-0,92$ & 0,23 & 0,03 & 0,46 \\
\hline Adaptation Nature & 110 & 4,37 & 0,62 & $-0,87$ & 0,23 & $-0,31$ & 0,46 \\
\hline Anomie & 110 & 3,00 & 1,07 & $-0,12$ & 0,23 & $-1,03$ & 0,46 \\
\hline Total & 110 & 4,15 & 0,46 & $-0,37$ & 0,23 & $-0,86$ & 0,46 \\
\hline
\end{tabular}

Is the sprititic well-being scale scores of patients diagnosed with cancer identified as the subproblem of our study significantly different from the educational level? findings were analyzed by ANOVA test. As a result of the analysis, it was found that the scale scores showed a significant difference in the $\mathrm{p}$ Anomi 1s sub-dimension ( $p<0.05)$.No significant difference was observed in other subdimensions and scale total score $[\mathrm{F}(4-109)=$ 2.03; $\mathrm{P}<0.05]$.Scheffe analysis was performed to determine the significant difference between the levels of education in the anomy subdimension, and it was found that there was a significant difference between the graduate level and all other fields of education ( $p>0.05$ ). According to this, the highest scale mean was $\mathrm{x}$ yüksek $=4.18$ at the graduate level, then high school $\mathrm{x}$ en $=3.15$; middle school $\mathrm{x}^{-}=2.90$; primary school $\mathrm{x}$ sapt $=2.78$ and license $\mathrm{x}^{-}=$ 2.39. The lowest score was obtained at the undergraduate level (Table 3).
It Is the sprititic well-being scale scores of patients diagnosed with cancer as meaningful? The results of the study were analyzed with ANOVA test. As a result of the analysis, it was found that there was a significant difference between the scale scores and education level only in Anomi sub-dimension ( $p>0.05$ ); no significant difference was observed in other sub-dimensions and scale total score [F (4-109) $=2.03 ; \mathrm{P}>0.05]$.Scheffe analysis was performed to determine the significant difference between the levels of education in the anomy sub-dimension, and it was found that there was a significant difference between the graduate level and all other fields of education ( $>$ 0.05). According to this, the highest scale mean was $\mathrm{x}=4.18$ at the graduate level, then high school $\mathrm{x}$ en $=3.15$; middle school $\mathrm{x}^{-}=$ 2.90; primary school $\mathrm{x}$ sapt $=2.78$ and license $\mathrm{x}^{-}$ $=2.39$. 
Table 3: Results of One-Way Variance Analysis (ANOVA) to determine whether the Scale Scores differ according to the Education Variable

\begin{tabular}{|c|c|c|c|c|c|c|c|c|c|c|c|}
\hline \multirow{2}{*}{\multicolumn{2}{|c|}{ Grup }} & \multirow{3}{*}{$\begin{array}{l}\mathbf{N} \\
29\end{array}$} & \multirow{3}{*}{\begin{tabular}{|r|} 
Mean \\
4,61 \\
\end{tabular}} & \multirow{3}{*}{\begin{tabular}{|r}
$\begin{array}{c}\text { Std. } \\
\text { Deviation }\end{array}$ \\
0,45
\end{tabular}} & \multirow{3}{*}{$\begin{array}{r}\text { Std. } \\
\text { Error }\end{array}$} & \multicolumn{6}{|c|}{ ANOVA } \\
\hline & & & & & & \multirow{2}{*}{$\begin{array}{l}\text { Between } \\
\text { Groups } \\
\end{array}$} & \multirow{2}{*}{\begin{tabular}{|r|}
$\begin{array}{c}\text { Sum of } \\
\text { Squares }\end{array}$ \\
0,89 \\
\end{tabular}} & \multirow{2}{*}{$\begin{array}{r}\text { df } \\
4\end{array}$} & \multirow{2}{*}{\begin{tabular}{r|}
$\begin{array}{c}\text { Mean } \\
\text { Square }\end{array}$ \\
0,22 \\
\end{tabular}} & \multirow{2}{*}{$\begin{array}{c}\mathbf{F} \\
1,12\end{array}$} & \multirow{2}{*}{\begin{tabular}{|l} 
Sig. \\
0,35
\end{tabular}} \\
\hline Transcendence & $\begin{array}{l}\text { Primary } \\
\text { school }\end{array}$ & & & & & & & & & & \\
\hline & $\begin{array}{l}\text { Middle } \\
\text { School }\end{array}$ & 22 & 4,60 & 0,31 & 0,07 & \begin{tabular}{|l|} 
Within \\
Groups
\end{tabular} & 21,00 & 105 & 0,20 & & \\
\hline & $\begin{array}{l}\text { High } \\
\text { school }\end{array}$ & 39 & 4,41 & 0,46 & 0,07 & Total & 21,89 & 109 & & & \\
\hline & License & 12 & 4,48 & 0,69 & 0,20 & & & & & & \\
\hline & $\begin{array}{l}\text { Master's } \\
\text { Degree }\end{array}$ & 8 & 4,54 & 0,08 & 0,03 & & & & & & \\
\hline & Total & 110 & 4,52 & 0,45 & 0,04 & & & & & & \\
\hline \multirow[t]{6}{*}{$\begin{array}{l}\text { Adaptation } \\
\text { Nature }\end{array}$} & $\begin{array}{l}\text { Primary } \\
\text { school }\end{array}$ & 29 & 4,52 & 0,56 & 0,10 & $\begin{array}{l}\text { Between } \\
\text { Groups }\end{array}$ & 1,72 & 4 & 0,43 & 1,12 & 0,35 \\
\hline & $\begin{array}{l}\text { Middle } \\
\text { School }\end{array}$ & 22 & 4,34 & 0,58 & 0,12 & \begin{tabular}{|l|} 
Within \\
Groups
\end{tabular} & 40,16 & 105 & 0,38 & & \\
\hline & $\begin{array}{l}\text { High } \\
\text { school }\end{array}$ & 39 & 4,29 & 0,67 & 0,11 & Total & 41,88 & 109 & & & \\
\hline & License & 12 & 4,52 & 0,56 & 0,16 & & & & & & \\
\hline & $\begin{array}{l}\text { Master's } \\
\text { Degree }\end{array}$ & 8 & 4,11 & 0,74 & 0,26 & & & & & & \\
\hline & Total & 110 & 4,37 & 0,62 & 0,06 & & & & & & \\
\hline \multirow[t]{6}{*}{ Anomie } & $\begin{array}{l}\text { Primary } \\
\text { school }\end{array}$ & 29 & 2,78 & 0,94 & 0,17 & \begin{tabular}{|l|} 
Between \\
Groups
\end{tabular} & 18,03 & 4 & 4,51 & 4,46 & 0,00 \\
\hline & $\begin{array}{l}\text { Middle } \\
\text { School } \\
\end{array}$ & 22 & 2,90 & 0,89 & 0,19 & \begin{tabular}{|l|} 
Within \\
Groups
\end{tabular} & 106,17 & 105 & 1,01 & & \\
\hline & $\begin{array}{l}\text { High } \\
\text { school }\end{array}$ & 39 & 3,15 & 1,02 & 0,16 & Total & 124,20 & 109 & & & \\
\hline & License & 12 & 2,39 & 1,31 & 0,38 & & & & & & \\
\hline & $\begin{array}{l}\text { Master's } \\
\text { Degree }\end{array}$ & 8 & 4,18 & 0,97 & 0,34 & & & & & & \\
\hline & Total & 110 & 3,00 & 1,07 & 0,10 & & & & & & \\
\hline \multirow[t]{6}{*}{ Total } & $\begin{array}{l}\text { Primary } \\
\text { school }\end{array}$ & 29 & 4,28 & 0,46 & 0,09 & $\begin{array}{l}\text { Between } \\
\text { Groups }\end{array}$ & 1,67 & 4 & 0,42 & 2,03 & 0,09 \\
\hline & $\begin{array}{l}\text { Middle } \\
\text { School } \\
\end{array}$ & 22 & 4,21 & 0,34 & 0,07 & \begin{tabular}{|l|} 
Within \\
Groups
\end{tabular} & 21,57 & 105 & 0,21 & & \\
\hline & $\begin{array}{l}\text { High } \\
\text { school }\end{array}$ & 39 & 4,05 & 0,49 & 0,08 & Total & 23,24 & 109 & & & \\
\hline & License & 12 & 4,28 & 0,53 & 0,15 & & & & & & \\
\hline & $\begin{array}{l}\text { Master's } \\
\text { Degree }\end{array}$ & 8 & 3,89 & 0,34 & 0,12 & & & & & & \\
\hline & Total & 110 & 4,15 & 0,46 & 0,04 & & & & & & \\
\hline
\end{tabular}

Another sub-problem of our study; According to the localization of the patients, do the spititual well-being scores of the patients differ significantly? The ANOVA test was used to 
determine whether the scale scores differed significantly between the groups [F (4-109) = $0.935, \mathrm{P}>0.05]$.

Another sub-problem of our study; Does the scores of the spititual well-being scale differ significantly according to the diagnosis time of the patients? The ANOVA test was used to analyze the findings and the scale scores were not significantly different between the groups [F $(4-109)=0.938, \mathrm{P}>0.05]$.

Another sub-problem of our study; Puan According to the last treatment methods of patients, do the scale scores of spititual wellbeing differ significantly? The ANOVA test was used to determine whether the scores of the scale differed significantly between the groups [F $(2-109)=0.238, \mathrm{P}>0.05]$.

According to age groups, the scores obtained from the patient's spiritual well-being scale were significantly different between the total score of the scale and the mean scores of the subscales of the sub-dimension of transcendence ( $p>$ 0.05); The mean scores of Adaptation to Nature and

Anomy subscales were not significantly different between the groups ( $p>0.05)$.In order to find

out the difference between the groups, the test was done firstly and the total score of the scale was homogeneous ( $p>0.05$ ), but the subdimension of transcendence was not homogeneous ( $\mathrm{p}$

$<0.05)$. For the size of the Tamhane test was done. According to Scheffe analysis of the significant difference in scale total scores, it was found that there was a significant difference

between the ages of 41-50 and 51-60 in terms of total score averages of the 51-60 age group. Significant differences in the sub-dimension of transcendence were found to be significantly different in favor of 51-60 age group among 4150 age group and 51-60 age group (Table 4). 
Table 4: Comparison of the Mean Average of Patients' Spiritual Well Being Scale and Age Intervals

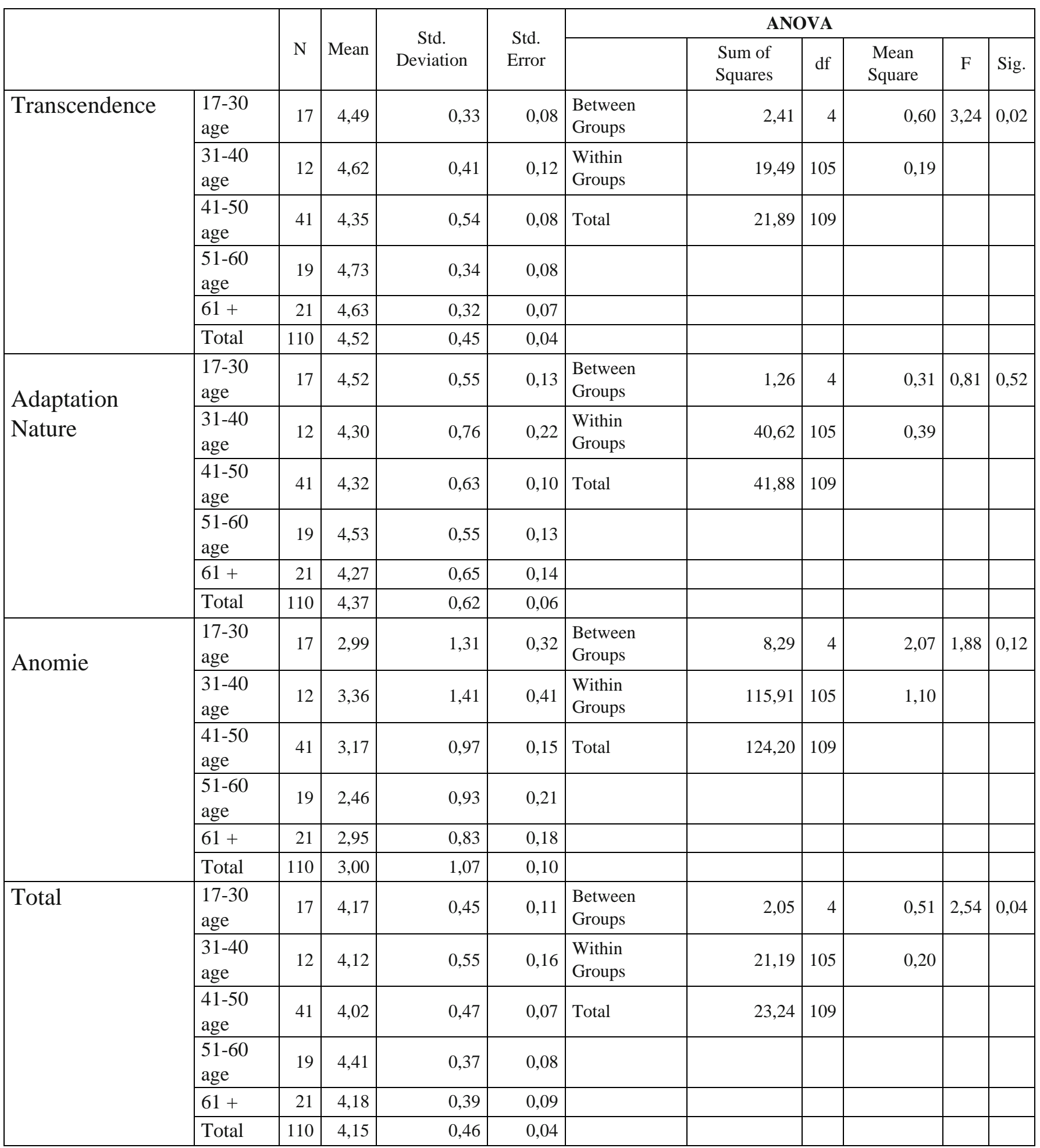

Do patients' scores of spiritual well-being differ significantly in terms of marital status? According to the $\mathrm{t}$ test results, no significant difference was observed between the groups ( $p>$
0.05). As a result of the independent group $t$ test, the difference between the arithmetic mean of the groups was statistically significant. There was no significant difference in the Adaptation 
with Nature $\mathrm{p}$ subscale $(\mathrm{t}=-0,12 ; \mathrm{p}>$ $.05)$, Transcendence $(\mathrm{t}=-4.55 ; \mathrm{p}<.05)$ in favor of men in the sub-dimension; Anomi $(\mathrm{t}=2,24 ; \mathrm{p}$
$<.05)$ was found to be in favor of women in the subscale and in terms of total score of the scale $(\mathrm{p}<.05)($ Table 4).

Table 5: Independent Group t Test Results to determine whether the Spiritual Well-being Scale Scores differ according to the Gender Variable

\begin{tabular}{|c|c|c|c|c|c|c|c|c|}
\hline \multicolumn{2}{|l|}{ Gender } & \multirow{2}{*}{$\begin{array}{l}\mathbf{N} \\
70\end{array}$} & \multirow{2}{*}{$\begin{array}{r}\text { Mean } \\
4,40\end{array}$} & \multirow{2}{*}{$\begin{array}{r}\text { Std. Deviation } \\
0,49\end{array}$} & \multirow{2}{*}{$\begin{array}{r}\text { Std. Error Mean } \\
0,06\end{array}$} & \multirow{2}{*}{$\begin{array}{l}\mathbf{t} \\
-4,55\end{array}$} & \multirow{2}{*}{$\begin{array}{l}\text { df } \\
107,21\end{array}$} & \multirow{2}{*}{$\begin{array}{r}\text { Sig. (2-tailed) } \\
0,00\end{array}$} \\
\hline Transcendence & Female & & & & & & & \\
\hline & Male & 40 & 4,73 & 0,26 & 0,04 & & & \\
\hline \multirow[t]{2}{*}{ Adaptation Nature } & Female & 70 & 4,37 & 0,64 & 0,08 & $-0,12$ & 108 & 0,90 \\
\hline & Male & 40 & 4,38 & 0,59 & 0,09 & & & \\
\hline \multirow[t]{2}{*}{ Anomie } & Female & 70 & 3,18 & 0,93 & 0,11 & 2,24 & 64,61 & 0,03 \\
\hline & Male & 40 & 2,68 & 1,23 & 0,19 & & & \\
\hline \multirow{2}{*}{ Total } & Female & 70 & 4,06 & 0,45 & 0,05 & $-2,85$ & 108 & 0,01 \\
\hline & Male & 40 & 4,31 & 0,44 & 0,07 & & & \\
\hline
\end{tabular}

As a result of the independent group t test, the difference between the arithmetic means of the groups was not statistically significant $(\mathrm{t}=$ $1.13 ; \mathrm{p}>.05)$. In favor of those without metastasis in the sub-dimension of transcendence $(\mathrm{t}=-2.03 ; \mathrm{p}<.05)$; Anomi $(\mathrm{t}=$
$1.68 ; \mathrm{p}<.05)$ was found to be in favor of those with metastasis in the sub-dimension, and in terms of total score of the scale, in favor of those without metastasis $(\mathrm{t}=-2.23 ; \mathrm{p}<.05)$ (Table 5).

Table 6: Independent Group t Test Results to determine whether the Spiritual Well-being Scale Scores differ according to the Metastasis Variable

\begin{tabular}{|c|c|c|c|c|c|c|c|c|}
\hline \multicolumn{2}{|c|}{ Spread Disease } & $\mathbf{N}$ & Mean & Std. Deviation & Std. Error Mean & $\mathbf{t}$ & df & Sig. (2-tailed) \\
\hline \multirow[t]{2}{*}{ Transcendence } & There is & 18 & 4,33 & 0,50 & 0,12 & $-2,03$ & 108 & 0,04 \\
\hline & No & 92 & 4,56 & 0,43 & 0,04 & & & \\
\hline \multirow[t]{2}{*}{ Adaptation Nature } & There is & 18 & 4,22 & 0,74 & 0,17 & $-1,13$ & 108 & 0,26 \\
\hline & No & 92 & 4,40 & 0,59 & 0,06 & & & \\
\hline \multirow[t]{2}{*}{ Anomie } & There is & 18 & 3,38 & 0,91 & 0,21 & 1,68 & 108 & 0,10 \\
\hline & No & 92 & 2,92 & 1,08 & 0,11 & & & \\
\hline \multirow{2}{*}{ Total } & There is & 18 & 3,93 & 0,47 & 0,11 & $-2,23$ & 108 & 0,03 \\
\hline & No & 92 & 4,20 & 0,45 & 0,05 & & & \\
\hline
\end{tabular}




\section{Discussion}

This study was carried out to determine the level of spiritual well-being of the patients who were admitted to the palliative unit of two state hospitals and who were diagnosed with cancer. Recently, it has been emphasized that the spiritual well-being of individuals is of vital importance for the health to survive, develop and cope with crisis situations in which health is impaired (Büssing and Koenig 2010, Vincensi and Burkhart 2014). The spiritual values and the level of spiritual well-being of individuals support life-raising and increasing hope (Bhatnagar et al. 2016).It is important that the spiritual well-being, which has such a positive effect on health, knows what strategies to cope with their diseases by the cancer patients who need it. In addition, the use of these strategies will be guiding the spiritual care of health professionals. For this purpose, it is necessary to determine the level of spiritual well-being of the patients and to develop supportive practices accordingly. Kardaş (2017) on spiritual wellbeing in the Turkish field literature wrote that) The Predictiveness of Virtual Identity and Spiritual Well-Being's Narcissistic Tendencies of University Students $r$ and Gürsu and Ay (2018) on iyi Religion, Spiritual Well-Being and Old-Age Türkçe it is available. However, this research is the first one since there is no study on the spiritual well-being of palliative care cancer patients. When the distribution of the descriptive characteristics of the participants included in the study was examined in a general framework, the average age was 46, 63.64\% was female, $35.45 \%$ of the education level $(\mathrm{n}=$ 39) and high school graduate $78.18 \%(\mathrm{n}=86)$ $31.82 \%(\mathrm{n}=35)$ were found to be housewives. When the localization of the cancer was examined, $25.45 \% \quad(\mathrm{n}=28)$ of the gastrointestinal tract; $\%$ and $33.64 \%(\mathrm{n}=37)$ had other cancer localization. When the time of diagnosis of the sample participating in the study is examined, the most frequent; It was determined that $49.09 \%(\mathrm{n}=54) 4-7$ months time elapsed and $83.64 \%(n=92)$ did not have spread disease. The most recent treatment method was $44.55 \%$ ( $\mathrm{n}=49)$. radiotherapy treatment (Table 1).Gürsu and Ay olarak (2018) found that $75 \%$ of the age group was $60-75$ years.

Fernsler et al. (1999) examined the spiritual well-being of patients with cholecular cancers in their study. More than half of the 121 participants were male (56\% male and $76 \%$ were married. In the study conducted by Gürsu and Ay (2018), when the spiritual well-being was grouped, the majority $(56 \%)$ were found to have a high level of spiritual well-being.

In this study, the mean total score of the scale was found to be $4,15 \pm 0,46$ ) and it was found to be at a good level. Recent research suggests that spirituality is a factor that has a positive effect on mental health during cancer (Boscaglia et al. 2005, Choumanova et al. 2006). In a study, it was reported that $93 \%$ of cancer patients sustain their hopes as a result of spiritual coping (Culliford 2002).

According to age groups, the total score obtained from the spiritual well-being scale of the patients and the mean scores of the subdimension of transcendence were significantly different between the age groups ( $p>0.05$ ); It was determined that the levels of spiritual wellbeing were higher than the participants aged 5160. These results support our study. In the literature, it was found that the age of spiritual well-being did not correlate with age and it was found not to be compatible with our study Laubmeier et al. 2004, Leak et al. 2008, McClain-Jacobson et al., 2004, McClain et al. 2003, McCoubrie 2006, Morgan et al. 2006, Perkins 2007, Visser, et al. (2010).Fernsler et al. (1999) examined the spiritual well-being of patients with cholecal cancer and found a 
difference in younger age (25-45). In the study of Kardaş (2017), when the spiritual well-being scale compares with the sub-dimensions of transcendence, harmony with nature, and anism in the analysis of the age group according to spiritual well-being, only the dimension of harmony with nature was found meaningful. Koenig (2001, 2002) emphasized that approximately $90 \%$ of patients over 60 years of age use religion to overcome the love of divine power to overcome health problems to help them cope with the feeling of trust. In the studies, it was observed that spiritual and religious coping methods were preferred among women, elderly people and individuals with low socioeconomic status (Boscaglia, Clarke, Jobling and Quinn 2005, Romero et al.2006).

In the study conducted by Gürsu and Ay (2018), no significant difference was found between the levels of spiritual well-being in terms of gender. In Kardaştedirs (2017) study, the level of spiritual well-being of university students varies significantly by gender. Kizilırmak (2015) in the study of the spirituality conceptualized by the meaning of life and the search for meaning in young adults, there is no difference according to gender. In this study, in order to determine whether there is a significant difference according to the gender variable, the independent group $t$ test results showed that the difference between the arithmetic mean of the groups was statistically significant. No concordance was found in the Compliance with Nature sub-dimension $(\mathrm{t}=-0,12 ; \mathrm{p}>$ $.05)$, Transcendence $(\mathrm{t}=-4.55 ; \mathrm{p}<.05)$ in favor of men in the sub-dimension; Anomi $(\mathrm{t}=2,24$; $\mathrm{p}$ $<.05)$ was found to be in favor of women in the subscale and in terms of total score of the scale $(\mathrm{t}=-2,85 ; \mathrm{p}<.05)$.

This result is thought to be due to the difference of the sample group and it is thought to be compatible with the purpose of the research. In a study conducted by Gürsu and Ay (2018), no significant relationship was found between total and sub-dimensions of spiritual well-being scale and marital status variable. No differentiation was observed in this study ( $p>0.05)$.

When the education level and spiritual wellbeing relationship were examined, it was found that there was a significant difference between the scale scores and education level only in Anomi sub-dimension ( $p>0.05$ ), there was a significant difference in other sub-dimensions and scale total score $[\mathrm{F}(4-109)=2.03 ; \mathrm{P}>0.05]$ was found to be at the graduate level with belir = 4.18.In the study conducted by Gürsu and Ay (2018), no significant difference was found between the level of education and spiritual well-being. In the literature, it is emphasized that age does not correlate with the educational level of spiritual well-being (Laubmeier et al. 2004, Leak et al, 2008, McClain-Jacobson et al. 2003, McClain et al. Leak et al. 2008, Visser, et al. 2010). It is inevitable for educational level to raise awareness and to question the meaning of life and to discover spiritual potentials in individuals and to contribute to spiritual wellbeing. The result of this study supports the positive contribution of education.

In the study, it was determined that the localization of cancer, the time of diagnosis, the last treatment methods and the scale of the spititual well-being scale were not significantly different between the groups. In the literature, it is not possible to make a comparison because there is no study on the state of these variables related to spiritual well-being.

\section{Conclusions and Recommendations:}

In our study, the levels of spiritual well-being of palliative care patients diagnosed with cancer were evaluated by a questionnaire. As a result, the mean total score of the palliative care patients diagnosed with cancer was found to be 
high $(4.15 \pm 0.46)$. This result is the result of palliative care patients have a sense of spiritual well-being, but because of lack of information, the result was inadequate. Spiritual well-being provides a positive effect on the healing process of individuals with impaired health. It helps the individual to understand life in cases of lifethreatening diseases such as cancer, in the provision of spiritual well-being in coping with this crisis. In this process, spiritual care initiatives by health professionals can be made part of the healing process and the spiritual well-being of the individual can be increased.

Similarly, the fact that healthcare professionals should be informed and educated on this issue is considered very important. Indeed, studies have shown that the majority of nurses are inadequate to meet the emotional and spiritual needs of terminally ill patients and their families. It is also necessary to develop and increase postgraduate-level education for the training of spiritual care specialists in Turkey, to ensure cooperation and coordination between these departments, to officially recognize the spiritual care profession, and to maintain the services under the state control. This is of great importance for the expansion of the service range that people, who need spiritual care or counseling support, especially palliative care that is considered as a human right, can reach it, and for a humanistic life and end of life. Further research in this area is expected to contribute to the enrichment of the relevant literature.

Author Contributions: F.Ç. and T.Ş. conceived and designed the study; F.Ç. and T.Ş. recruited participants; F.Ç. conducted data collection; F.Ç. analyzed the data; T.Ş. and F.Ç. wrote the paper; and T.Ş. edited and reviewed the paper.

Funding: This research received no external funding.
Conflicts of Interest: The authors declare no conflict of interest.

\section{References:}

1. American Association of Pastoral Counselors

(AAPC).

http://www.aapc.org , (Accessed Date: 05.11.2018)

2. American Cancer Society Cancer Research Program. https://www.cancer.org/research. html, (Accessed Date: 21.12.2018)

3. American Cancer Society Cancer Statistics Center. https://cancerstatisticscenter.canc er.org/\#!/, (Accessed Date: 21.12.2018)

4. Arslan H, Konuk Şener D.(2009). Studying The Concepts Of Stigma, Spirituality And Comfort In Accordance With Meleis' Concept Development Process. Maltepe University Journal of Nursing Science and Art, 2 (1): 51-58.

5. Atabek, EA, Karadağ, A. (2013). Nursing principles: nursing science and its principles. İstanbul: Akademi Printing and Publishing; 2013; 1136-37.

6. Bhatnagar, S. Noble, S., Chaturvedi, S. K., \&Gielen, J. Development and psychometric assessment of a spirituality question naire for Indian Palliative Care Patients. Indianjournal of Palliativecare. 2016; 22(1): 9-18.

7. Boscaglia, N., Clarke, D. M., Jobling, T. W., \& Quinn, M. A. (2005). The contribution of spirituality and spiritual coping to anxiety and depression in 
women with a recent diagnosis of gynecological

cancer. International Journal of Gynecological Cancer, 15(5), 755-761.Büssing, A., \& Koenig, H. G. (2010). Spiritual needs of patients with chronic diseases. Religions, 1(1), ss. 1827.

8. Catania, G., Bagnasco, A., Zanini, M., Aleo, G., \& Sasso, L. (2016). Spiritual assessment within clinical interventions focused on quality of life assessment in palliative care: a secondary analysis of a systematic review. Religions, 7(3), 25.

9. Choumanova I, Wanat S, Barrett R, Kopman C (2006). Religion and spirituality in coping with breast cancer: Perspective of Chilean women. The Breast Journal, 12 (4): 349-352.

10. Culliford, L. (2002). Spirituality and clinical care: Spiritual values and skills are increasingly recognised as necessary aspects of clinical care.

11. Çınar, F., \& Eti Aslan, F. (2017). Spiritualism and nursing: the importance of spiritual care in intensive care patients. JAREN: Journal of Academic Research in Nursing, 3(1), 37-42.
12. Doyle, Derek and Roger Woodruff (2013). The IAHPC Manual of Palliative Care 3rd Edition, International Associaciation for Hospice and Palliative Care (IAHPC) Press, https://hospicecare.com/uploads/201 3/9/The \%20IAHPC\%20Manual\%20 of\%20Palliative\%20Care\%203e.pdf, (Accessed Date: 21.12.2018).

13. Ekşi, H., \& Kardaş, S. (2017). Spiritual well-being: Scale development and validation. Spiritual Psychology and Counseling, 2, 7388. http://dx.doi.org/10.12738/spc. 20 $\underline{17.1 .0022}$

14. Elçigil, A. (2006). Pediatrics palliative care and nursing. Journal of Anatolian Nursing and Health Sciences, 9 (4), 75 81 .

15. Ellor, W.J. ve McGregor, J.A. (2011).Reflection on Words "Religion", "Spiritual WellBeign" and "Spirituality. Journal of Religion, Spirituality and Aging. 23,275-278.

16. Fisher, J. W. (2007). It's Time to Wake Up and Stem The Decline in Spiritual Well-Being in Victorian Schools. International Journal of Childeren's Spirituality.12(2), 165-177.

17. Glare P. Clinical predictors of survival in advanced cancer. $\mathbf{J}$ Support Oncol 2005;3(5):331-9.

18. Gow, A. Watson, J. R., Whiteman, M. ve Deary, I. J. (2011). A Stairway to Heaven? Structure of the Religious Involvement Inventory and 
Spiritual Well-Being Scale. J

Relig Health. 50: 5-19.

19. Gürsu, O., \& Ay, Y. (2018).

Religion, spiritual well-being and aging Journal of International Social Research, 11(61).

20. Kalkim, Asl1, Tulay S. Midilli, and Ebru Baysal. 2016. An Investigation of the Perception Sand Practices of Nursing Students Regarding Spirituality and Spiritual Care. Religions 7: 101.

21. Karasar, N. (2000). Scientific research method. Ankara: Nobel Publication Distribution.

22. Khairunnisa AD (2014). Spirituality and nursing. Journal of Holistic Nursing, Amerikan Holistic Nurses, 32(4): 341-46.

23. Koenig HG.(2001). The Healing Power of Faith. New York: Simon\&Schuster; 2001. s.11231.

24. Koenig HG.(2002). A commentary: The Role of Religion and Spirituality At The End of Life. 42(Special issue3), s. 20-3.

25. Kostak, A. Melahat, Ülfiye Çelikkalp, and Melike Demir. 2010. The Opinions of Nurses and Midwifes about Spirituality and Spiritual Care. Symposium Special Issue, Maltepe University Journal of Nursing Science and Art, 218-25

26. Kuzeyli-Yildirim Y. (2006). Caring for the cancer patient at home. Inside: Fadıloğlu Ç, Doğan F, Ertem G. editors. Home care. İzmir: Meta Printing Printing Services; p. 269-87.
27. Laubmeier, K. K., Zakowski, S. G., \& Bair, J. P. (2004). The role of spirituality in the psychological adjustment to cancer: A test of the transactional model of stress and coping. International Journal of Behavioral Medicine, 11(1), 48.

28. Leak A, Hu J, King CR. Symptom distress, spirituality, and quality of life in African American breast cancer survivors. Cancer Nurs 2008;31:E15-E21.

29. Leak A, Hu J, King CR. Symptom distress, spirituality, and quality of life in African American breast cancer survivors. Cancer Nurs 2008;31:E15-E21

30. Lundbergand PC, Kerdonfag P.(2010). Spiritual care provided by Thai nurses in intensive care units. Journal of Clinical Nursing, 19: 1121-28.

31. McClain CS, Rosenfeld B, Breitbart W. Effect of spiritual well-being on end-of-life despair in terminally-ill cancer patients. Lancet 2003;361:1603-1607.

32. McClain-Jacobson C, Rosenfeld B, Kosinski A, Pessin H, Cimino JE, Breitbart W. Belief in an afterlife, spiritual well-being, and end-of-life despair in patients with advanced cancer. Gen Hosp Psychiatry 2004;26:484-486.

33. McCoubrie R, Davies A. Is there a correlation between spirituality and anxiety and depression in patients with advanced cancer? Support Care Cancer 2006;14:379-385. 
34. McDowell, L., \& South, R. (2017). Christians' Perceptions of Receiving Spiritual Care in the Bible Belt of the United States: A Qualitative Study of Care Provided in the Healthcare Setting. Religions, 8(7), 127.

35. Meier DE. Palliative care in U.S. Hospitals: implications for access to quality healthcare, testimony prepared for the United States Senate Special Committee on Aging. 2008. 1-23.

36. Morgan PD, Gaston-Johansson F, Mock V. Spiritual well-being, religious coping, and the quality of life of African American breast cancer treatment: a pilot study. ABNF J 2006;17:73-77.

37. Narayanasamy A. (2006). The impact of empirical studies of spirituality and culture on nurse education. Journal of Clinical Nursing, 15(7): 840-51.

38. Paloutzian F. Raymond ve Crystal L. Park (Editör) (2013). Din ve maneviyat psikolojisi temel yaklaşımlar ve ilgi alanlarl. Original Name: Handbook of the psychology of religion and spirituality. (Trans. İhsan Çapcioğlu ve Ali Ayten). Phoenix Yayınları, ISBN: 978605-4657-57-5

39. Perkins EA, Small BJ, Balducci L, Extermann M, Robb C, Haley WE. Individual differences in well-being in older breast cancer survivors. Crit Rev OncolHemat 2007;62:74-83.

40. Romero C, Kalidas M, Elledge R, Chang J, Liscum KR, Friedman LC (2006). Selfforgiveness, spirituality, and psychological adjustment in women with breast cancer. J Behav Med, 29 (1): 29-36.

41. Tabachnick, B.G. and Fidell L.S, (2013). Using Multivariate Statistics (sixth ed.) Pearson, Boston.

42. Toker, K., \& Çınar, F. (2018). Perceptions of Spirituality and Spiritual Care of Health Professionals Working in a State Hospital. Religions, 9(10), 312.

43. Turan T, Yavuz Karamanoğlu A. (2013). Determining intensive care unit nurses' perceptions and practice levels of spiritual care in Turkey. Nursing in Critical Care, 18(2): 70-8.

44. Unterrainer, HF., Nelson, O., Collicutt, J. ve Fink, A. (2012). The English Version of The Multidimensional Inventory for Religious/Spiritual Well-Being (MI-RSWB-E): First Re-sults from British College Students. Religions. 3, 588-599.

45. Vincensi BB, Burkhart L. Development and Psychometric Testing of New Instruments to Assess Nurse Practitioners' Provision of Spiritual Care. J HolistNurs. 2016; 34(2):112-22

46. Visser, A., Garssen, B., \& Vingerhoets, A. (2010). Spirituality and well-being in cancer patients: a review. Psycho-oncology, 19(6), 565-572. 
47. World Health Organization (WHO), WHO Definition of Palliative Care. http://www.who.int/cancer/palliative /definition/en/, (Accessed Date: 21.12.2018).

48. Yıldız, E., Dedeli, Ö., Pakyüz, S. Ç. (2016). Evaluation of Care Burden and Quality of Life among Family Caregivers of
Patients with Cancer. Journal Of Nursing Education And Research 2016; 13 (3): 216-225.

49. Y1lmaz M, Okyay N. (2013). Yilmaz M, Okyay N. (2013). Nurses' views on spirituality and spiritual care. Journal of Research and Development in Nursing, 2009; 3: 41-52

\section{AUTHOR BIOGRAPHY}

Fadime Çınar, Sabahattin Zaim University, Faculty of Health Sciences, Health Management, Istanbul, Turkey

Turgay Şirin, Sabahattin Zaim University, Faculty of Human And Social Sciences, Psychology, Istanbul, Turkey 